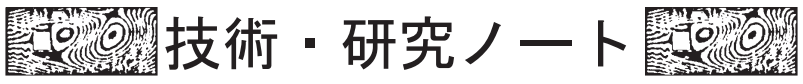

\section{GPS 搭載位置追跡システムによる鳥類の個体移動経路の取得 Application of GPS Tracking System to Moving Path Acquisition of Birds}

\author{
西尾真由子* 1 \\ Mayuko NISHIO \\ 井上美樹*2 \\ Miki INOUE \\ 時田賢一* 5 \\ Ken-ichi TOKITA
}

\author{
藤野陽三* 3 \\ Yozo FUJINO \\ 今井金美*6
}

Kanemi IMAI
樋口広芳* 4

Hiroyoshi HIGUCHI

矢澤正人 $* 7$

Masato YAZAWA

\section{SUMMARY}

This study examined the applicability of a GPS tracking system for birds in prospect of future requirements to consider the symbiosis with the bird life in the construction and operation of wind turbines on the coastal area or on the ocean. The target here to apply the GPS tracking system was the crow in the Yokohama-city, which was expected to show complex moving paths in the urban area. Six crows were caught in the Yokohama National University campus, and the GPS device was put on each of their backs before releasing. The positional data were then acquired every 30 minutes for 14 days with the success rate of $90 \%$ or more in five out of six crows. The data were applicable to understand the characteristic moving path of each crow.

key words: bird life symbiosis, wind turbine, GPS tracking sensor, crows, moving path

\footnotetext{
* 1 横浜国立大学大学院都市イノベーション研究院 准教授 nishio@ynu.ac.jp Associate Professor, Department of Civil Engineering, Yokohama National University

* 2 横浜国立大学理工学部 (研究当時在籍)

Undergraduate Student, Department of Civil Engineering, Yokohama National University

* 3 横浜国立大学先端科学高等研究院 上席特別教授

Distinguished YNU Professor, Institute of Advanced Sciences, Yokohama National University

* 4 東京大学名誉教授, 慶應義塾大学訪問教授

Professor Emeritus of the University of Tokyo, Visiting Professor, Keio University

* 5 岩手大学/NECoRA *6 株式会社 シー・アイ・シー

Iwate University / NECoRA Civil International Corporation

* 7 株式会社 数理設計研究所

Mathematical Assist Design Laboratory

(原稿受理年月日：2018 年 1 月 24 日，採用決定年月日：2018 年 7 月 16 日)
} 


\section{1。まえがき}

人間が社会生活を営む上で必要不可欠であるインフラ 構造物の建設は, 周囲の自然環境とりわけ野生動物の生 態とも共生を行うべきものである。筆者らが特に着目し ているのが，自然エネルギーへの関心の高まりを背景と して建設が進められる風力発電施設と野生鳥類との共生 である。風車の建設台数が増加していくことが予想され る一方で，その主な建設場所となる沿岸部や洋上地域が 渡り鳥をはじめ多種多様な鳥類の飛行経路の一部, もし くは餌場や住みかとなる場所でもあり得ることから，そ れらの生態が施設の建設や運用に与える影響が懸念され ている。風力発電の導入が進む欧州では, 風車への衝突 により死亡する鳥類の総数は数百羽と推定されている ${ }^{1)}$ 国内の風車における鳥類衝突事故は 2001 年から 2014 年 の報告で年間平均 50 件に満たないが, タカ科やカモメ科, カラス科の鳥類の衝突事故数が特に多く, 特にタカ科の 中で天然記念物および絶滅危惧種に登録されているオジ ロワシの事故が多いことが報告されている2）その他，ミ サゴやイヌワシなどの希少種も含まれており, 死亡事故 による個体数の変化が種の存続に影響を及ぼしかねず問 題視されている3)。さらに風車建設が鳥類の生息地放棄や 移動ルートの障壁となることも調査報告されており ${ }^{2)}$, 鳥 類生態への影響は無視できないといえる。また発電施設 の運用という観点でも鳥類衝突事故によって事業が滞る ことは損失も大きい。生態学分野の既往研究では, 鳥類 生態と共存するための風力発電施設稼働モデル構築も行 われている ${ }^{4)}$ 。この問題に対して有効な対策の 1 つが, 風 車の建設段階で鳥類の活動拠点や移動経路に関する客観 的なデータを取得し，鳥類生態への影響の大きい地域を 避けて風力発電施設を建設することである ${ }^{122)}$ 。英国では, 風車建設が鳥類生態に与える影響評価を実施してマッピ ングを行い，事業策定段階から検討に用いることが紹介 されている5)。ただし, このような風力発電施設と鳥類生 態の共生一の検討はこれまで主に生態学分野にて実施さ れてきている。施設を建設して運用する事業者側, それ に関わる土木分野でもこのような鳥類生態に関寸る客観 的データを取得して, 建設段階から共生を考えていくこ とが重要となる。そこで本研究では, 鳥類衝突問題の検 討で有用な情報となる移動経路追跡技術に着目した。

鳥類の移動経路データの取得方法として, まず挙げら れるのがレーダーを用いる方法である。レーダーの作動 面に鳥の群れが飛ぶと電波を散乱させてエコーが発生し， それを解析して飛行経路を推定できる。欧米では渡り鳥
のモニタリング手法として既に積極的に採用され，成果 をあげている 9-8)。日本でもこのレーダーによる観測手法 の適用事例がある。例えば, 気象レーダー「ウィンドプ ロファイラ」による渡り鳥の夜間追跡調查などの既往研 究や ${ }^{9)}$, 船舶レーダーを垂直方向に適用して鳥の飛翔高度 と移動方向と速度を計測した事例 ${ }^{10)}$ などが挙げられる。 ただしこの方法は鳥類の群れとしての動きを捉えるのに 適切であるが，個体の行動追跡はできない。これに対し て, 個体に端末を装着し発信電波を受信して移動経路を

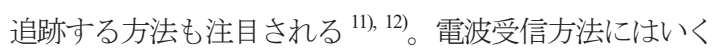
つかあり，例えば，観測者がデータ受信用アンテナを持 って電波の到来方向を測定するラジオテレメトリー法, 固定アンテナで受信して位置を推定する方法がある。こ れらの方法は, 狭い範囲内での個体移動経路の追跡に適 している。一方, 広範囲での移動経路を把握することが できる手法として, PHS (Personal handy-phone system) 端 末装着による手法が登場し, これを適用してカラスの移 動経路追跡を実施した既往研究がある ${ }^{13)}$ 。この研究では, 東京都内で PHS 発信機を装着したハシブトガラス計 66 羽の追跡を行いカラスの移動パターンを導き出すことに 成功し, その追跡手法としての有用性も示された。近年 では GPS (Global positioning system) の端末小型化や位置 情報高精度化が進み，これを利用した野生動物の移動経 路追跡が可能となっている。土木分野でも風力発電施設 の建設・運用と鳥類生態との共生を検討するための客観 的なデータとして，このような位置追跡システムによる 個体移動経路を取り扱えれば非常に有用である ${ }^{14)}$

本論文では, 特に動物移動経路追跡用に開発された GPS 搭載位置追跡システムを用いて横浜都市部に生息す るハシブトガラス (以下, カラス) の移動経路追跡を実 施した結果を報告する。電波送受信の難易度が高い大都 市部で本システムを適用し, 複雑な行動パターンを有す るカラスを対象として移動経路の取得を行った。土木分 野の研究者・技術者が将来, 風力発電施設などの建設と 運用で動物生態との関連を検討寸る際に, 個体移動経路 追跡技術を活用できる足掛かりを築くことを狙いとした。

\section{G P S 端末装着によるカラス個体移動経路取得}

2. 1 G P S 搭載位置追跡システムの概要

本研究では, 横浜国立大学構内に生息するカラスを対 象として移動経路データの取得を行った。動物のリアル タイム移動経路追跡用に開発された GPS 搭載位置追跡シ ステム (GPS-TX, (株) 数理設計研究所製) を使用した。 このシステムは動物個体に装着する GPS 搭載装置と, そ 
こから送信される電波を受信する基地局からなる。GPS の測位精度は $6 \mathrm{~m}$ (CEP, 50\%), 25m (2dRMS, 95\%) の仕様 である。基地局で受信した緯度経度の位置情報は, GPS-TX システム専用の地図可視化システム TMS (Trace Mapping System) によってスマートフォンやタブレット 端末からリアルタイムで確認できる。このシステムは既 往研究において, 岩手県盛岡市のカラスを対象に個体の 移動経路特性の把握に用いられた実績があった ${ }^{15)}$ 。本研 究は横浜市のカラスを対象としたことで, 高層ビル群を 含む大都市部での初めての適用事例となった。

GPS-TX 個体装着装置の内蔵バッテリーの性能では計 500 回程度の位置情報発信が可能である。ただし, 基地局 側でデータ受信に失敗しても端末側では 1 回分の送信と してバッテリーは消耗されるため, 基地局からの電波状 況が悪ければ取得デー夕数は減少する。また個体が GPS 測位の困難な箇所, 例えば建物等の陰に滞在していると, 1 回のデータ取得で位置情報発信を 2-3 分間継続するた め, 通常 1 分未満で完了寸る開けた場所での測位と比較 して 2-3 倍のバッテリー消耗となる。本研究では, 大学 構内で最も高い標高に位置して横浜市街地も広く見通せ る高層建物（9階建て）の屋上に基地局を設置した。図 1 は，この基地局設置箇所でのデータ受信性能を事前確認 するために実施した電波伝搬シミュレーションの結果で ある。基地局から $15 \mathrm{~km}$ 範囲のほぼ全域が着色範囲, 寸 なわち GPX-TX 仕様上での電波受信可能範囲であった。 都市部に生息するカラスの移動距離はおよそ $10 \mathrm{~km}$ まで との報告もあり ${ }^{16)}$ ，この基地局設置箇所で大学構内を拠 点とするカラスの行動経路を概ね捉えられることを確認 した。ただし，このシミュレーション結果は建造物の影 響を考慮しおらず, 目安としての受信性能把握に用いた。

\section{2 対象個体の捕獲と装着}

GPS 搭載装置を装着するカラス個体の捕獲は, 2014 年 12 月 18 日から 2015 年 1 月 14 日の期間に行った。横浜 国立大学構内でカラスが特に多くみられるエリアの建物 の屋上に, 一旦外から入ると出られない仕掛けのある木 製小屋（約 $3.0 \mathrm{~m} \times 3.9 \mathrm{~m} \times 2.7 \mathrm{~m} ）$ を設置し，小屋の内外に 餌を撒いて小屋内に誘い込んた。捕獲できた 10 羽のうち 平均的な体長 50-60 cm の 6羽のカラスに, 個体装着装置 をテフロン加工された布製のハーネスで背中に取り付け (図 2)，放鳥した。ハーネスは肩ひも同士の縫い合わせ 方を調整することにより，1-2 か月後には鳥体から脱落 するようになっている。機器と八ーネスは合わせて約 $30 \mathrm{~g}$ であり, 平均的なカラスの体重 550-750g ${ }^{16)}$ の 5\%程度に おさまる重量であった。

\section{3 データ取得状況}

本研究では GPS-TX システムのデータ取得間隔を 30 分 に設定し， 2 週間程度の追跡期間を目指した。表 1 に, 放 鳥した 6 羽各個体（ID-1 ID-6）のデータ取得状況をまと める。「開始日時」は放鳥を行った日時であり,「終了日 時」は最後のデータが得られた日時である。実際に得ら れたデータ数を「総受信数」とし，この中で明らかにエ ラーと認められたデータを除いたデータの数を「有効デ ータ数」とした。「有効データ取得率」は,「総受信デー 夕数」に対する「有効デー夕数」の割合である。

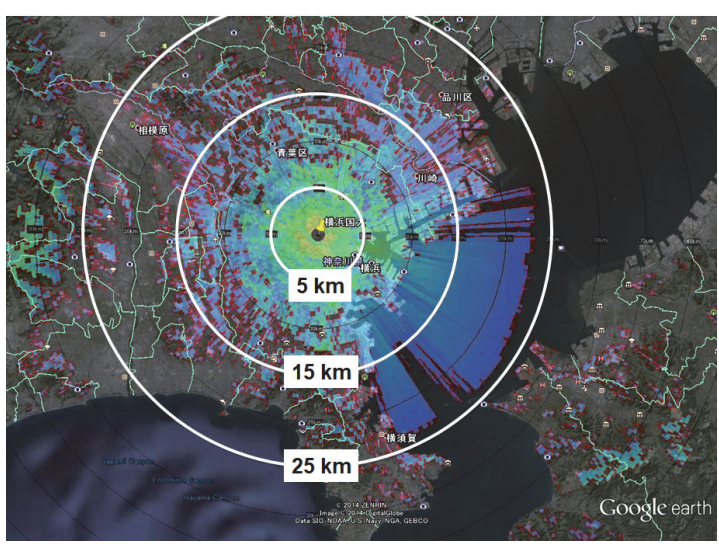

図 1 横浜国立大学建物屋上に基地局を設置した際の 電波伝搬シミュレーション

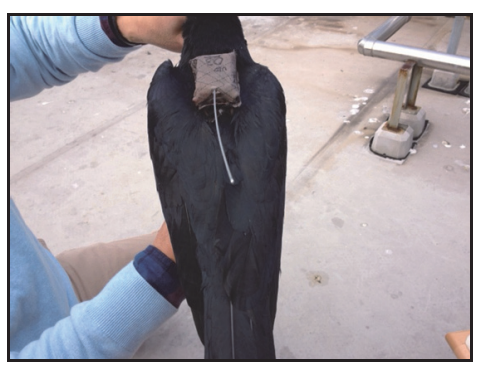

図 2 ハシブトガラス個体への GPS 搭載装置の装着

表 1 各個体のデータ取得状況

\begin{tabular}{|c|c|c|c|c|c|c|}
\hline & ID-1 & ID-2 & ID-3 & ID-4 & ID-5 & ID-6 \\
\hline 開始日時 & $1 / 14$ & $1 / 14$ & $1 / 14$ & $1 / 14$ & $1 / 14$ & $1 / 14$ \\
& $13: 45$ & $13: 49$ & $13: 53$ & $13: 58$ & $14: 05$ & $14: 09$ \\
\hline 終了日時 & $\begin{array}{c}1 / 21 \\
18: 15\end{array}$ & $\begin{array}{c}1 / 18 \\
1: 25\end{array}$ & $\begin{array}{c}1 / 22 \\
20: 01\end{array}$ & $\begin{array}{c}1 / 23 \\
18: 04\end{array}$ & $\begin{array}{c}1 / 28 \\
4: 03\end{array}$ & $\begin{array}{c}1 / 27 \\
22: 13\end{array}$ \\
\hline $\begin{array}{c}\text { 総受信 } \\
\text { データ数 }\end{array}$ & 343 & 169 & 378 & 436 & 632 & 638 \\
\hline $\begin{array}{c}\text { 有効 } \\
\text { データ数 }\end{array}$ & 301 & 66 & 336 & 424 & 615 & 620 \\
\hline $\begin{array}{c}\text { 有効デー } \\
\text { タ取得率 }\end{array}$ & $88 \%$ & $39 \%$ & $89 \%$ & $97 \%$ & $97 \%$ & $97 \%$ \\
\hline
\end{tabular}




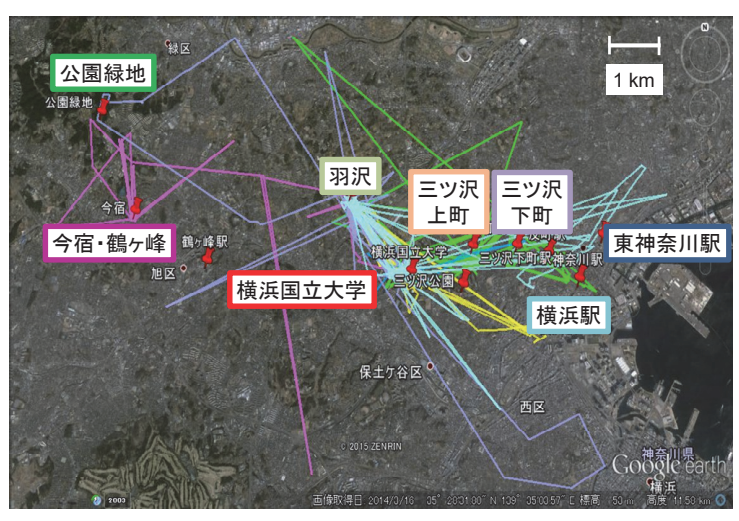

図 35 個体のデータ取得期間中移動経路プロット (ID-1: 黄色，ID-3: 薄青, ID-4: 赤紫, ID-5: 緑, ID-6: 薄紫)

個体の移動を追跡できた期間は，最短が ID-2 での約 4 日間, ID-5 と ID-6 は目標通り 14 日間で総数 600 を超え る位置情報データが受信できた。一方，ID-1 から ID-4 の 4 台は, センサの仕様上可能な 500 回の受信に届かないま ま途切れてしまった。これは，個体が GPS 測位の困難な 箇所に滞在する頻度が多く位置情報発信を繰り返したこ とで, 著しくバッテリーを消耗したことが主な原因と考 えられる。また受信できた位置情報の中にも，カラスの 生態から考えて明らかに移動できないような箇所の緯度 経度データ, 例えば遠方の海洋上の緯度経度が数点受信 される，というようなエラーが認められた。この原因に も，個体が GPS 測位環境の悪い地点に滞在したことによ る測位不良が主に考えられる。特にデータ取得率が $39 \%$ と他の個体と比較して極端に低かった ID-2 は, このよう なエラーデータの割合も多かった。しかし, 本研究で初 めて GPS-TX システムを大都市部の鳥類移動経路計測に 適用したなかで，横浜市の中心部（保土ヶ谷区・横浜駅 周辺など）を行動範囲に含むカラス 6 個体のうち 5 個体 で移動経路の分析に用いることができるデータが取得で きた。ID-2 以外の 5 羽では 1 週間以上のリアルタイム行 動追跡に成功しており, また有効デー夕率も $90 \%$ 程度で あった。そこで次章の移動経路分析は ID-2 を除く 5 羽に ついて行うこととした。なお，分析では上記の明らかな エラーデータを生データから取り除いて用いた。

\section{3. 取得データからの個体移動経路の分析と考察}

3. 1 個体ごとの移動経路特性

本研究で GPS-TX システムにて取得したデータは, 各 個体から送られてきた各時間の緯度経度である。はじめ に, 5 個体で得られた計測期間中の移動経路データを全て

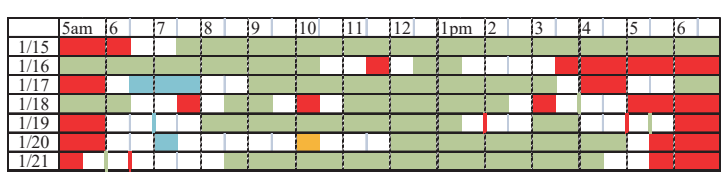

(a) ID-1（赤: YNU 構内, 薄緑: 羽沢町, 薄青: 横浜駅 周辺, 橙: 三ツ沢公園周辺)

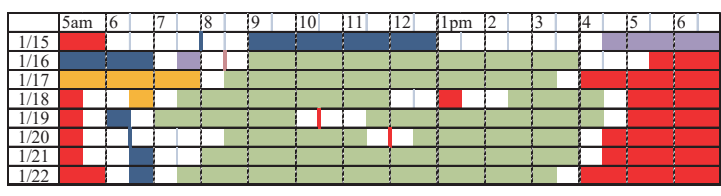

(b) ID-3 (赤: YNU 構内, 薄緑: 羽沢町, 濃青: 東神奈川駅

周辺, 橙: 三ツ沢公園周辺, 薄紫: 三ツ沢下町)

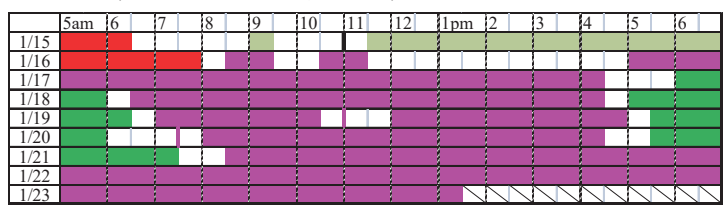

(c) ID-4（緑: 公園緑地，赤紫: 鶴ヶ峰・今宿, 赤: YNU 構内, 薄緑: 羽沢町)

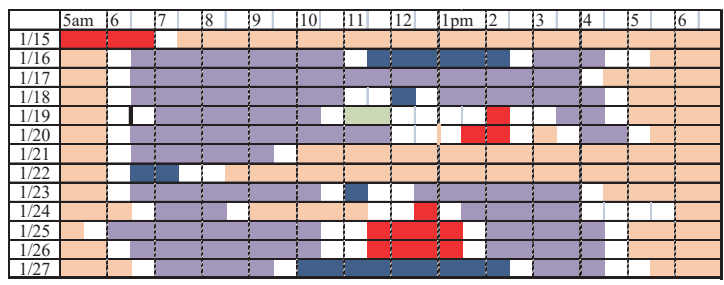

(d) ID-5（薄橙: 三ツ沢上町，薄紫: 三ツ沢下町， 濃青: 東神奈川駅周辺, 赤: YNU 構内, 薄緑: 羽沢町)

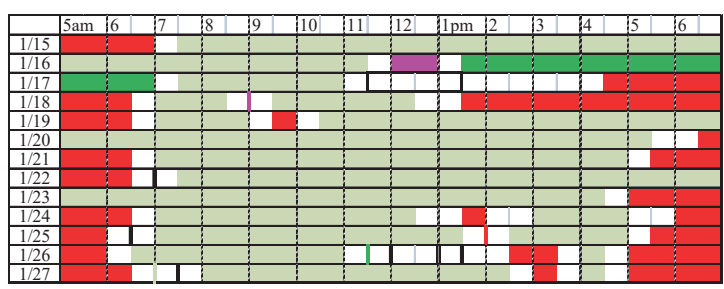

(e) ID-6 (赤: YNU 構内, 薄緑: 羽沢町, 緑: 公園緑地, 赤紫: 鶴ヶ峰・今宿)

図45 個体（ID-1/3/4/5/6）の滞在エリアと滞在時間

航空写真上に重ねて, 図 3 に示した。まず, 全ての個体 の行動範囲が大学構内の基地局から $10 \mathrm{~km}$ の範囲に概ね おさまっていたことがわかった。そしてデータ取得期間 中で 5 個体のうち最も行動範囲が広かったのは ID-6 であ り, 一方, ID-1 は横浜国立大学周辺の比較的狭い範囲で 決まった地点を行き来していた。また，ID-4 は計測期間 中大学周辺にはほとんど带在せず, 西側の今宿エリアを 拠点に活動していた。このように緯度経度のプロットか 
ら各個体の行動パターンを視覚的に把握できた。さらに, 各個体の滞在地点と移動経路を時系列で把握するため, 取得データを図 4 のように整理した。30 分毎のデータか ら滞在しているエリアを分類し，色に分けて記した。す ると各個体のねぐらや, 日中特に長い時間滞在する地点, そして日中の平均移動距離と時間を把握寸ることができ た。各個体の移動経路の特徵を, 以下にまとめる。

ID-1: ねぐらは大学構内の中央広場の樹林であり, 日中は 羽沢エリアで過ごしていた。1/17, 19,20には, 必ず 朝に横浜駅周辺を訪れる行動がみられた。1 日の滞 在地数は日によってばらつき，2-4 箇所であった。

ID-3: 日中多くの時間を羽沢エリアで過ごしており, ねぐ らは大学構内の樹林であった。計測期間全体を通し て，1 日に移動する距離が長い傾向にあった。1/19 以降には必ず朝に東神奈川駅周辺に行く行動がみ られた。1 日の滞在地数は, 平均 3 箇所であった。

ID-4: 大学近辺に滞在していたが, 1/17 以降は西側の今宿 エリアから公園緑地エリアを活動圈としており, ⿰ ぐらも同エリアの樹林としていた。1 日の滞在地数 は平均で 2 箇所と, 他の個体より少なかった。

ID-5: ねぐらを三ツ沢上町, 日中の活動場所を三ツ沢下町 としていた。また ID-3 と同様に東神奈川エリアを 活動圈に含むが, 訪れるのは朝ではなく, 必ず昼前 から午後であった。この個体も 1 日の滞在地点数は 日によってばらつき，2-4 箇所であった。

ID-6: 行動パターンは ID-3 と類似しており, ねぐらは大 学構内の樹林, 日中は羽沢エリアで過ごすことが多 かった。しかし時折, $5 \mathrm{~km}$ 以上の長距離移動を行う

日もあった。1 日の滞在地点数は2-3䇢所であった。

いずれの個体も, 1 日にねぐらを含めて 2 から 4 か所程度 の地点を移動していた。日中の滞在地点は個体ごとにあ る程度決まっており, 各地点を訪れる時間帯や順番にも 個体ごとのパターンがみられた。

3. 2 特徵的な滞在地点における現地調査

GPS-TX 位置追跡システムのリアルタイムデータ表示 機能を活用して, 各個体の位置情報を確認しながら滞在 している地点の特徵を調べる現地調查を行った。以下に, 各個体がねぐらと日中の活動地点としていた主要な 5 地 点について, その特徴をまとめる。

(a) 横浜国立大学周辺エリア

構内には樹林がしげっている箇所が多く, 夜間にねぐ らとなっていることが確認できた。さらに滞在地点を詳 細にみると, 大学構内でも, ねぐらとしている地点は個 体毎にほぼ決まっていた。 (b) 羽沢町エリア

ID-1，ID-3，ID-6 の日中の活動拠点で，畑とまとまった 樹林が多かった。またいずれの個体も特に頻繁に訪れて いたのがこのエリアにある家畜小屋であり，現地調査で も多くのカラスが出入りする様子を確認した。施設管理 者の話から，カラスは概ねトウモロコシなど牛の䬶を目 当てに小屋の中に入ってくるとのことであった。

(c-1) 鶴ヶ峰・今宿町, (c-2) 公園緑地エリア

このエリアを活動拠点としていたのはID-4 である。滞 在地点は住宅地やゴルフ場で, 周辺に樹林が茂っていた。 また, ねぐらとしての利用があった北側の公園緑地は, 比較的規模の大きな公園が集中していた。 (d-1) 三ツ沢上町, (d-2) 三ッ沢下町エリア

このエリアには樹林が広く広がる寺院があり, ID-5 は ここをねぐらとしていた。さらに住宅地の中にも採食が 可能な畑が存在している他，ゴミ収集場もカラスにより 荒らされている箇所があった。

(e) 東神奈川駅周辺エリア

このエリアには公園と寺院が多くあり, 住宅や駅周辺 に商業施設が立ち並ぶ一方で自然も多く存在する地域で あった。特筆すべき点がごみ収集場の状況で，収集日に 現地調查に赴くと多くの収集箇所がカラスに荒らされて いた。ID-3 と ID-5 の訪れる頻度が高かったが，2 個体と もとれぞれ早朝と正午前後の決まった時間帯に訪れてい た。滞在地点を詳細にみると, エリア内で多数の地点を 転々と移動する傾向が見られ，ごみ収集前後での採食目 的であったことが推察された。

以上のように GPS 位置データ取得と合わせて現場調査 を実施した結果，各個体が頻繁に訪れるエリアには共通 する特徽があることがわかった。1つ目は「まとまった樹 林」の存在であり，特にねぐらとしての利用が多かった (a)大学周辺エリアや(d-1)三ツ沢上町, (c-2)公園緑地エリ アには, 広範囲での樹林があった。2つ目が畑や家畜小屋, ごタ収集場といった「餌を確保できると考えられる地点」 の存在であり,これらは日中の滞在地点となっていた。

このように, GPS 搭載位置追跡システムを用いて行動 経路分析を実施することで, 各個体の行動パターンを把 握でき，現地調查を合わせて実施することでその行動パ ターンの誘因要素となる各地点の特徴を分析できた。

\section{4. 結論}

本研究では, 風力発電施設の建設や運用において鳥類 生態との共生を検討する際に用いるデータとして, 個体 への GPS 搭載装着で得られる移動経路に着目し, カラス 
を対象としてその適用性への検討を行った。得られた知 見を以下にまとめる。

・ GPS 搭載装置を装着し放鳥した 6 羽のうち 5 羽で, 行動分析に有効な位置情報データを取得できた。う ち 3 羽では 10 日間以上にわたって 30 分毎の緯度経 度データが受信成功率 $97 \%$ で得られた。

・ 6 羽のうち 1 羽は, データ取得率 $34 \%$ で受信が停止 した。これは GPS 測位および基地局へのデータ送信 でエラーが何度も発生し, 個体装着装置のバッテリ 一を著しく消耗したためであると考えられる。

・ 取得データから各個体の行動範囲, 小ぐら, 日中の 滞在地点や滞在時間など, 行動経路のパターンを定 量的に把握できた。データと合わせて現地調査を実 施した結果, 各個体が頻繁に滞在するエリアには, ねぐらや休息場所となる樹林，および畑や家畜小屋 など採食行動が可能な場所があることが把握された。 本研究で用いた GPS-TX システムのように, 個体装着 型の動物位置追跡システムではデバイスの小型化や位置 情報の高精度化が進み，鳥類の個体移動経路把握に適用 可能なデータ取得が可能であることがわかった。このよ うなシステムでは装着デバイスのバッテリー性能でデー 夕の通信回数と容量が決まることから, 対象と寸る鳥類 の生態に応じて基地局の設置箇所やデータ取得間隔を策 定する必要がある。例えば, データ取得間隔を長くして 月・年単位の長期データを取得できれば，季節変化や気 象条件の移動経路一の影響も分析できる。また本研究で は, 緯度経度のみを取得して通信容量を押さえ, データ 取得期間と安定性を確保した。これらに加えて高度デー タも取得すれば, 滞在地での行動や飛行ルートの分析を より詳細に行うことができる。風力発電施設の建設時や 運用時に鳥類生態把握に用いるデータとして, より有用 なものとなることが期待できる。

\section{謝辞}

本研究を実施するにあたり, 東京大学名誉教授であら れる板生清先生に, ウェアラブルセンサを用いた移動体 位置情報データ取得についてご指導ご助言を賜りました。 ここに記し，深く感謝いたします。

\section{参考文献}

1) 日本野鳥の会,「風力発電の鳥類に与える影響に関す る評価」,pp. 111-161, (2004)

2)浦達也，「風力発電が鳥類に与える影響の国内事例」， 野外鳥類学論文集, 31,pp. 3-30, (2015)
3）松田裕之，「日本における風力発電の可能性と鳥衝突 問題」，風力エネルギー, 32(2),pp. 31-37, (2008)

4) 島田泰夫, 松田裕之,「風力発電事業における鳥類衝 突リスク管理モデル」，保全生態学研究，12, pp. 126-142, (2007)

5) 松本真由美,「生物多様性との両立を図る風力発電の 開発」, 風力エネルギー, 38 (1), pp. 24-28, (2014)

6) Gauthreaux Jr, S. A., Belser, C. G., "Radar ornithology and biological conservation,” The Auk, 120 (2), pp. 266-277 (2003)

7) Gasteren, H. V., Holleman, I., Bouten, W., Loon, E. V., Shamoun- Baranes, J. U. D. Y., "Extracting bird migration information from C-band Doppler weather radars," Ibis, 150 (4), pp. 674-686, (2008)

8) Dokter, A. M., Liechti, F., Stark, H., Delobbe, L., Tabary, P., Holleman, I., "Bird migration flight altitudes studied by a network of operational weather radars," Journal of the Royal Society Interface, 8 (54), pp. 30-43 (2011)

9）植田睦之, 島田泰夫, 有澤雄三, 樋口広芳,「気象レー ダー「ウィンドプロファイラ」により明らかにな った全国的な渡り鳥の移動状況」, Bird Research, 5, A9-A18, (2009)

10) 藤吉康志，「ライダーやレーダーを利用した鳥の高度 飛行・経路の調查研究紹介」北海道大学低温研究所 低温研ニュース, 2009年1月 No.26, http://www.lowtem. hokudai.ac.jp/newsletter/news26a.pdf, (2017. 7)

11) 板生清,「ウェアラブルへの挑戦」, 工業調査会, (2001)

12）樋口広芳，「高度情報通信技術を利用した野生動物の 移動追跡」, 日本生態学会誌, 51, pp. 205-214, (2001)

13）森下英美子, 樋口広芳, 「都市におけるハシブトガラ スの局地移動」，カラスの自然史（樋口広芳 編, 北 海道大学出版) , pp. 53-69, (2010)

14）井上美樹, 藤野陽三, 西尾真由子, 樋口広芳, 時田賢 一, 矢澤正人,「土木構造物と生物の共生に向けた生 体観測としての GPS センサによるカラス行動経路 追跡」, 平成 27 年度日本風工学会年次研究発表会梗 概集, pp. 95-96, (2015)

15) 藤田紀之, 服部俊宏, 東淳樹, 尾上舞, 矢澤正人, 瀬 川典久,「ハシブトガラスの行動圈特性の把握と個体 数調整対策のための計画圈域の検討」, 農村計画学会 誌, 34 (2), pp. 160-166, (2015)

16）環境省自然環境局，「自治体担当者のためのカラス対 策マニュアル（基礎・現状編）（資料編）」（2001） 